\title{
Mugwort pollen season in the air of Poland in 2019
}

\author{
Małgorzata Puc ${ }^{1}$, Piotr Rapiejko ${ }^{2,3}$, Agnieszka Lipiec ${ }^{4}$, Małgorzata Malkiewicz', Katarzyna Dąbrowska-Zapart ${ }^{6}$, \\ Grzegorz Siergiejko ${ }^{7}$, Marta Dmitruk ${ }^{8}$, Alina Stacewicz ${ }^{9}$, Dariusz Jurkiewicz ${ }^{10}$, Ewa Kalinowska ${ }^{3}$ \\ ${ }^{1}$ Institute of Marine \& Environmental Sciences, University of Szczecin, Poland \\ ${ }^{2}$ Department of Otolaryngology with Division of Cranio-Maxillo-Facial Surgery in Military Institute of Medicine, \\ Warsaw, Poland \\ ${ }^{3}$ Allergen Research Center, Warsaw, Poland \\ ${ }^{4}$ Department of Prevention of Environmental Hazards and Allergology, Medical University of Warsaw, Poland \\ ${ }^{5}$ Department of Palaeobotany, Institute of Geological Sciences, University of Wroclaw, Poland \\ ${ }^{6}$ Department of Paleontology and Stratigraphy, Faculty of Earth Sciences, University of Silesia in Katowice, Poland \\ ${ }^{7}$ Pediatrics, Gastroenterology and Allergology Department, University Children Hospital, \\ Medical University of Bialystok, Poland \\ ${ }^{8}$ Department of Botany and Plant Physiology, University of Life Sciences in Lublin, Poland \\ ${ }^{9}$ Department of Botany and Nature Conservation, Faculty of Biology, University of Szczecin, Poland \\ ${ }^{10}$ Department of Otolaryngology with Division of Cranio-Maxillo-Facial Surgery in Military Institute of Medicine, \\ Warsaw, Poland
}

\begin{abstract}
:
The Asteraceae family is one of the largest families, comprising 67 genera and 264 species in Poland. However, only a few genera, including Artemisia, are potential allergenic sources. The aim of the study was to compare the mugwort pollen seasons in Bialystok, Bydgoszcz, Sosnowiec, Lublin, Piotrkow Trybunalski, Opole, Olsztyn, Szczecin, Warsaw and Wroclaw in 2019. The investigations were carried out using the volumetric method. Seasonal Pollen Index was estimated as the sum of daily average pollen concentrations in the given season. The mugwort pollen season is mainly observed in June, July and at the beginning of September. In 2019 the pollen season of mugwort started first in Opole, on the June $26^{\text {th }}$. At the latest, a pollen season ended in Bydgoszcz and Warsaw, at the end of September. The differences of pollen seasons duration were extremely considerable, from 35 to 83 days. The highest airborne concentration of 97 pollen grains $/ \mathrm{m}^{3}$ was noted in Lublin on the July $31^{\text {st. The maximum }}$ values of seasonal pollen count in Polish cities occurred between July $28^{\text {th }}$ and August $12^{\text {th }}$, most often between in late July and early August. The highest mugwort pollen allergen hazard occurred in 2019 in Lublin, Warsaw, Opole and Wroclaw, and was 2-3 times higher than in other cities. The highest variability in the analysed seasons was found in start date, while the lowest in the peak value and SPI value. In the pollen season in 2019, 2 peaks of Artemisia pollen concentrations were observed as a result of the order of flowering of $A$. vulgaris and $A$. campestris. Information on the pollination of various Artemisia species will be used to avoid excessive exposure to allergens of these pollen grains.
\end{abstract}

Key words: aeroallergens, pollen count, mugwort (Artemisia L.), 2019

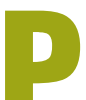
ollen allergens of the Artemisia L. genus (mugwort) are among the most frequent and serious causes of pollinosis in many parts of the world [1]. The genus Artemisia is found throughout almost the whole of Europe, from the Mediterranean zone in the south to the sub-Arctic zone in the north. The majority of European species of Artemisia grow in southern and southeastern regions with continental climate. Occurrence of the Artemisia species is associated with dry or slightly moist habitats and full exposure to light, which are important components of the steppes [2]. In the inland saline habitats of eastern Europe, A. maritima is found. Some species of Artemisia are connected with the mountainous regions of 
southern and central Europe, e.g. A. eriantha. A number of species in Europe frequently occur in habitats transformed by human activities. There are about 50 native species of Artemisia altogether in Europe. 18 species grow in Poland, half of them are alien species naturalised in the native Polish flora. Of the 9 other species, 6 are regarded as native (A. absinthium L. var. calcigena, A. campestris L., A. eriantha Ten., A. pontica L., A. scoparia Waldst. \& Kit. and A. vulgaris L.), while another 3 species are cultivated. Only 3 native species of Artemisia are commonly found in Poland (A. absinthium, A. campestris, A. vulgaris) [2].

Artemisia pollen is present in the air for over 10 weeks, generally from mid-July until mid-September. In central and northern Europe the optimum of pollination falls in mid-August. After peak day, the flowering season may last until September. Artemisia is one of the very few genera in the family Asteraceae comprising wind-pollinated plants. Despite wind dispersal and high pollen productivity (an individual plant produces 38 million pollen grains), mugwort pollen is relatively poorly distributed. Much of the pollen does not rise higher than 3-10 $\mathrm{m}$ above ground level, which limits its wider distribution $[1,3]$.

From an aerobiological point of view the most important Artemisia species are considered to be pioneer plants that colonise disturbed soils in urban and rural environments and are especially found on agricultural fields, roadside verges, abandoned places and where building activities take place [4].

The species of the genus Artemisia are involved in strong cross-reactions observed in the patomechanism of allergy. Mugwort pollen cross reacts with almost all other Composites, especially with ragweed pollen. Further cross reactions are known with dandelion, goldenrod, sun flower, chamomilla, and all the daisy-like flowers. Very important cross-reactions are known in the frame of food-allergies with celery [1].

Aim

The aim of the study was to compare the mugwort pollen concentrations in the air of Bialystok, Bydgoszcz, Sosnowiec, Lublin, Opole, Olsztyn, Piotrkow Trybunalski, Szczecin, Warsaw, Wroclaw and Zielona Gora in 2019 as well as to indicate the highest risk of pollen allergens in individual cities.

\section{Material and method}

Measurements of bioaerosol were carried out in the selected cities of Poland, in Bialystok, Byd- goszcz, Sosnowiec, Lublin, Opole, Olsztyn, Piotrkow Trybunalski, Szczecin, Warsaw, Wroclaw and Zielona Gora in 2019. Measurements were performed by the volumetric method. The used devices, which are recommended by the IAA (International Association for Aerobiology), take air samples (Burkard and Lanzoni pollen sampler) in volumes corresponding to average human respiratory parameters [5].

The duration of the pollen season was determined by the $98 \%$ method [6], assuming that the onset and end of the season were days with recorded $1 \%$ and $99 \%$ of the annual total of pollen grains, respectively. The total pollen count over this period was expressed by the SPI (Seasonal Pollen Index).

On the basis of literature data, the number of days was determined in which concentrations of pollen of the Artemisia genus exceed the threshold values of consecutive allergy symptoms' development (tab. 1) [7].

\section{Results and discussion}

During the 3 years of phenological research conducted in Poznan, the following order of flowering of mugwort species (the most commonly represented in Poland) was observed: A. vulgaris first began flowering, then $A$. absinthium and A. campestris [8]. The analysis of Artemisia pollen seasons in this paper also showed this flowering order, which is presented in figures $1-6$. Blue and gray arrows indicate dates when peak pollen concentrations appear. Artemisia absinthi$u m$, which flowers in early August, shows the lowest pollen count among these 3 species. In figures 1-6, no visible increase in $A$. absinthium concentrations was observed during the pollen season in 2019, therefore this taxon is not marked on the figures using the arrows. While, peak values in A. vulgaris (late July, blue arrow in the figures) and $A$. campestris (mid-August, gray arrow in the figures) were marked. Information on the pollination of various Artemisia species will be used to avoid excessive exposure to allergens of these pollen grains.

In 2019 mugwort pollen season started between June $26^{\text {th }}$ in Opole and July $24^{\text {th }}$ in Wroclaw and lasted until the end of September in Bydgoszcz and Warsaw (tab. 1, figs 1-6). While in 2014 the Artemisia pollen season in most Polish cities started the earliest on June $13^{\text {th }}$ [9]. In 2015 the mugwort pollen season began only at the beginning of July [10]. In 2019, the longest pollen season in Warsaw lasted 83 days; a year earlier, in 2018 in Zielona Gora and Bydgoszcz, the season exceeded 3 months (110 days) [11]. 
Table 1. Characteristics of mugwort pollen season in 2019.

\begin{tabular}{|c|c|c|c|c|c|c|c|c|c|c|c|}
\hline Features of pollen season/city & $\begin{array}{l}\text { Bialy- } \\
\text { stok }\end{array}$ & $\begin{array}{l}\text { Byd- } \\
\text { goszez }\end{array}$ & $\begin{array}{l}\text { Sosno- } \\
\text { wiec }\end{array}$ & Lublin & Olsztyn & Opole & $\begin{array}{l}\text { Szcze- } \\
\text { cin }\end{array}$ & $\begin{array}{l}\text { Piotrkow } \\
\text { Tryb. }\end{array}$ & Warsaw & Wroclaw & $\begin{array}{l}\text { Zielona } \\
\text { Gora }\end{array}$ \\
\hline $\begin{array}{l}\text { Duration of pollen season } \\
\text { (number of days) }\end{array}$ & $\begin{array}{c}17 \mathrm{VII-} \\
19 \mathrm{IX} \\
(58)\end{array}$ & $\begin{array}{c}9 \mathrm{VII-} \\
28 \mathrm{IX} \\
(82)\end{array}$ & $\begin{array}{c}23 \mathrm{VII-} \\
19 \mathrm{IX} \\
(59)\end{array}$ & $\begin{array}{c}15 \mathrm{VII-} \\
15 \mathrm{IX} \\
(63)\end{array}$ & $\begin{array}{c}15 \mathrm{VII}- \\
12 \mathrm{IX} \\
(61)\end{array}$ & $\begin{array}{c}26 \mathrm{VI}- \\
10 \mathrm{IX} \\
(77)\end{array}$ & $\begin{array}{c}16 \text { VII- } \\
3 \mathrm{IX} \\
(50)\end{array}$ & $\begin{array}{c}12 \mathrm{VII-} \\
19 \mathrm{IX} \\
(70)\end{array}$ & $\begin{array}{c}6 \text { VII- } \\
26 \text { IX } \\
(83)\end{array}$ & $\begin{array}{c}24 \text { VII- } \\
27 \text { VIII } \\
(35)\end{array}$ & $\begin{array}{l}3 \mathrm{VII-} \\
12 \mathrm{IX} \\
(72)\end{array}$ \\
\hline $\begin{array}{l}\text { Seasonal Pollen Index SPI } \\
\text { (total) }\end{array}$ & 599 & 888 & 509 & 1193 & 785 & 981 & 657 & 797 & 1077 & 915 & 843 \\
\hline Peak value and peak date & $\begin{array}{c}76 \\
(28 \mathrm{VII})\end{array}$ & $\begin{array}{c}78 \\
(29 \mathrm{VII})\end{array}$ & $\begin{array}{c}65 \\
(4 \mathrm{VIII})\end{array}$ & $\begin{array}{c}97 \\
(31 \mathrm{VII})\end{array}$ & $\begin{array}{c}76 \\
(31 \mathrm{VII})\end{array}$ & $\begin{array}{c}84 \\
(4 \mathrm{VIII})\end{array}$ & $\begin{array}{c}51 \\
(29 \mathrm{VII})\end{array}$ & $\begin{array}{c}66 \\
(4 \mathrm{VIII})\end{array}$ & $\begin{array}{c}63 \\
(29 \mathrm{VII})\end{array}$ & $\begin{array}{c}89 \\
(7 \mathrm{VIII})\end{array}$ & $\begin{array}{c}55 \\
(12 \mathrm{VIII})\end{array}$ \\
\hline Days $\geq 30$ grains $/ \mathrm{m}^{3}[7]^{*}$ & 4 & 9 & 4 & 12 & 9 & 12 & 7 & 9 & 16 & 13 & 13 \\
\hline Days $\geq 55$ grains $/ \mathrm{m}^{3}[7]^{* *}$ & 3 & 4 & 3 & 11 & 3 & 8 & 2 & 4 & 5 & 8 & 4 \\
\hline Days $\geq 70$ grains $/ \mathrm{m}^{3}[7]^{* * *}$ & 1 & 1 & 0 & 4 & 1 & 3 & 0 & 0 & 0 & 5 & 0 \\
\hline
\end{tabular}

* First allergy symptoms

${ }^{* *}$ Allergic reactions in all patients.

${ }^{* * *}$ Acute symptoms in most patients.

Figure 1. Mugwort pollen count in Bialystok and Bydgoszcz in 2019.

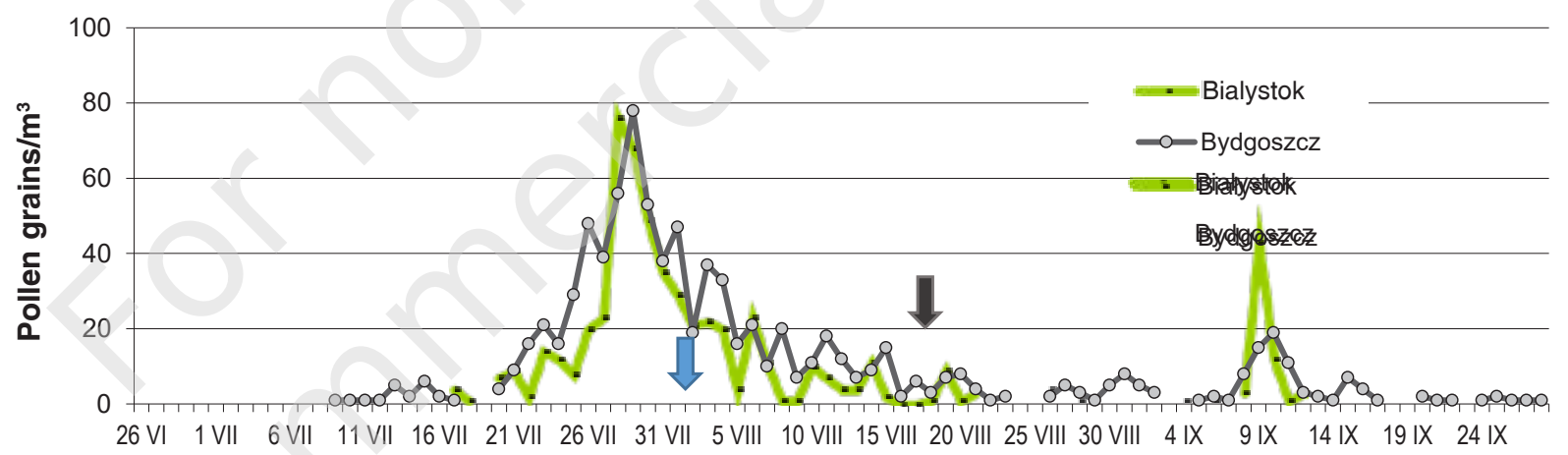

Figure 2. Mugwort pollen count in Sosnowiec and Lublin in 2019.

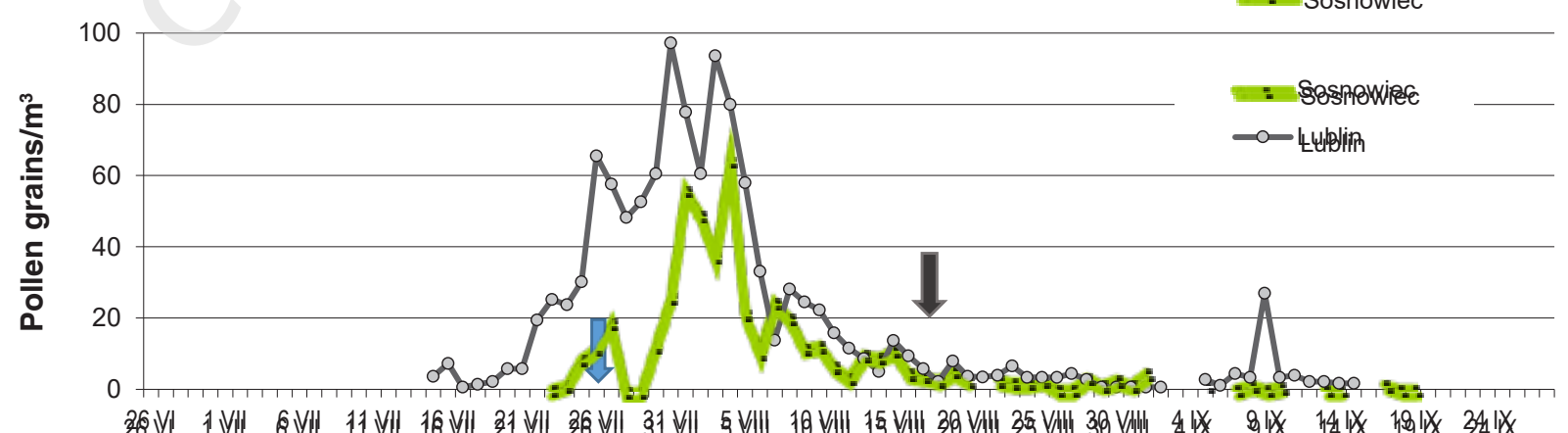

Figure 3. Mugwort pollen count in Olsztyn and Opole in 2019.

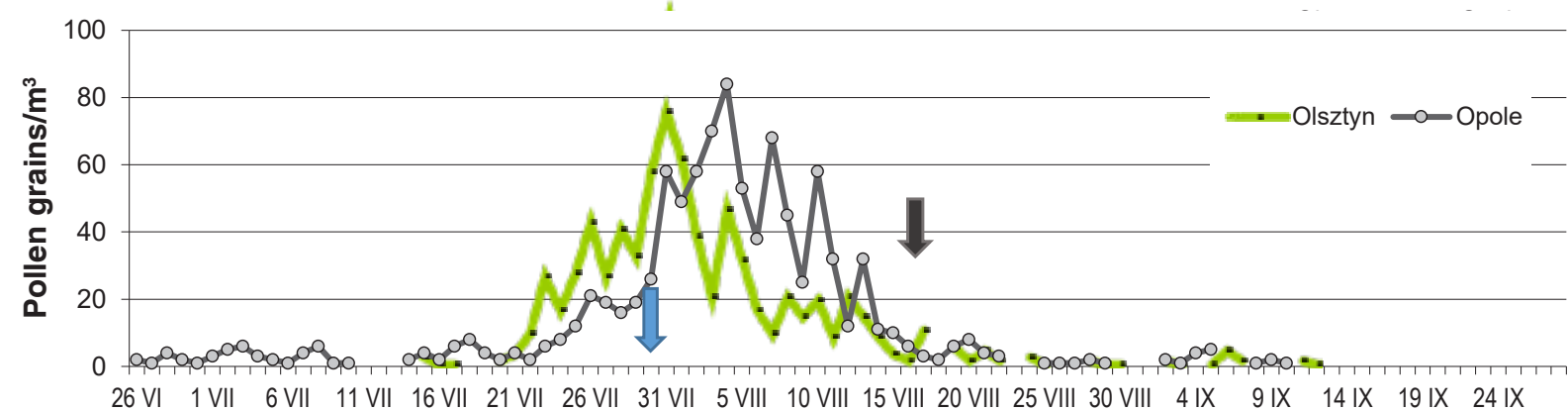


Figure 4. Mugwort pollen count in Szczecin and Piotrkow Trybunalski in 2019.

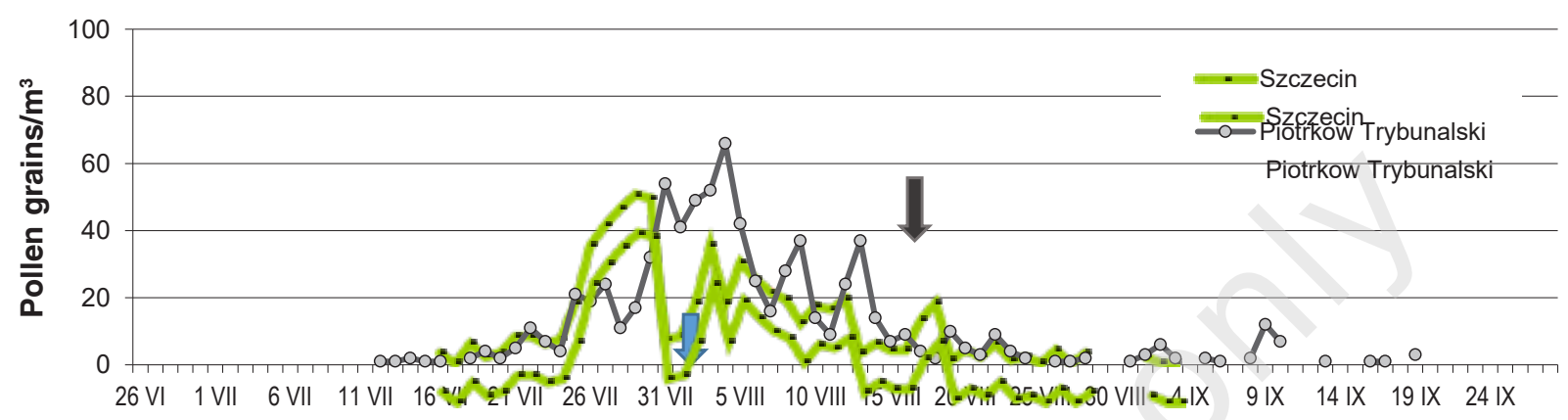

Figure 5. Mugwort pollen count in Warsaw in 2019.

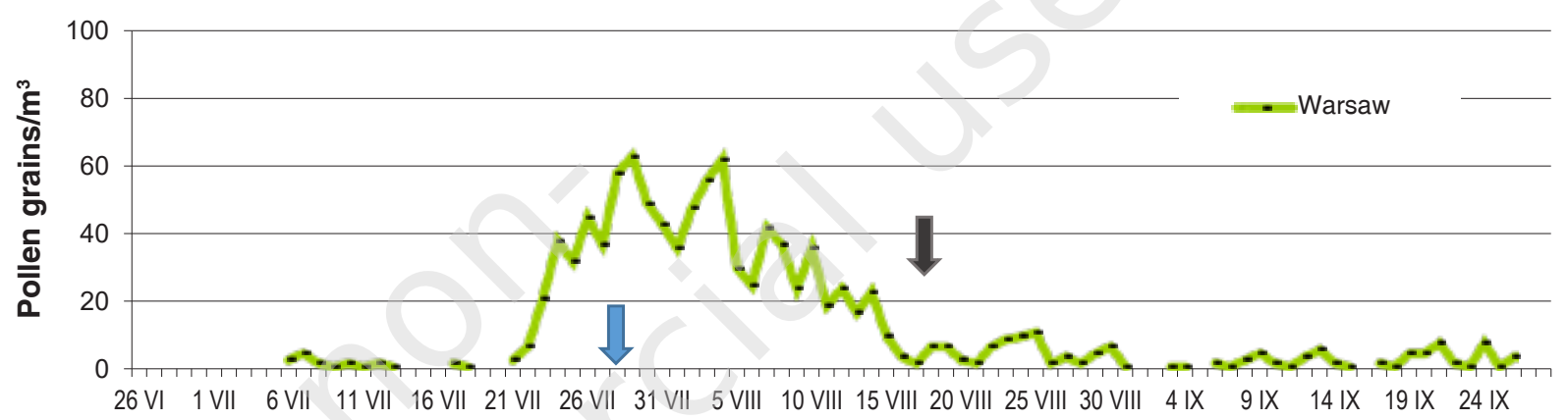

Figure 6. Mugwort pollen count in Wroclaw and Zielona Gora in 2019.

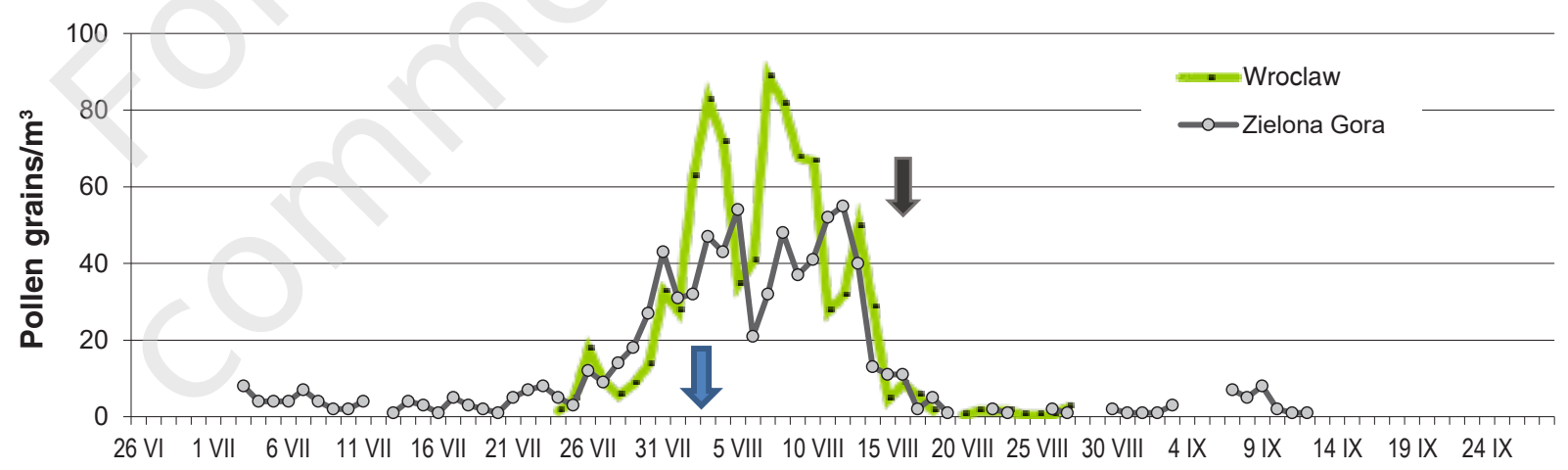

Blue arrow - estimated increase $A$. vulgaris pollen concentration.

Grey arrow - estimated increase $A$. campestris pollen concentration.

SPI values in 2019 ranged between 600 and 1200, in 2018 these values were similar within 350-1100 [11], while in 2014 SPI exceeded 1300 in Lublin [9].

The highest daily pollen count of mugwort was noted in 2019 in Lublin on July $31^{\text {st }}$ (97 grains $/ \mathrm{m}^{3}$ ) (tab. 1, fig. 2) and the highest annual sum of Artemisia pollen grains (SPI) was observed also in Lublin; in 2014 [9] the maximum daily concentration was observed August $19^{\text {th }}$ in Poznan (172 grains $/ \mathrm{m}^{3}$ ) in 2018 [11] - August $3^{\text {rd }}$ in Lublin, and similarly in 2015 [10] - August $7^{\text {th }}$ in Bydgoszcz.

The highest mugwort pollen allergen hazard occurred in 2019 (above 150 grains $/ \mathrm{m}^{3}$ ) in Lublin and lasted 5 days. The comparison of these taxa's pollen seasons in previous years revealed that in 2014 [9] pollen concentrations were much lower than in 2019 with the exception of Poznan, where the number of days with concentrations above the threshold value was very high and this period lasted almost the entire month. In 2018 the highest peak value was reached in Lublin ( 88 grains $/ \mathrm{m}^{3}$ ) with 2 weeks when the threshold values for mugwort pollen were exceeded [11].

The research conducted by Oteros et al. [12] in Germany have shown that the majority of airborne endotoxin stems from bacteria dispersed with pollen of only one plant: mugwort. This endotoxin was essential for inducing inflammation of the lung and allergic sen- 
sitization. Endotoxin (LPS) released from gram-negative bacteria causes strong immunologic and inflammatory effects and, when airborne, can contribute to respiratory conditions, such as allergic asthma. More than $60 \%$ of the annual endotoxin exposure was detected in the particulate matter PM $>10$ fraction, showing that bacteria do not aerosolize as independent units or aggregates but adhere to large particles. In Munich $70 \%$ of annual exposure was detected between June $12^{\text {th }}$ and August $28^{\text {th }}$. Multivariate modeling showed that endotoxin levels could be explained by phenological parameters (i.e. plant growth). Indeed, days with high airborne endotoxin levels correlated well with the amount of Artemisia pollen in the air. Pollen collected from plants across Europe (100 locations) showed that the highest levels of endotoxin were detected on Artemisia vulgaris (mugwort) pollen, with little on other pollen. Microbiome analysis showed that LPS concentrations on mugwort pollen were related to the presence of Pseudomonas species and Pantoea species communities. In a mouse model of allergic disease, the presence of endotoxin on mugwort pollen was needed for allergic sensitization.

\section{Conclusions}

Artemisia pollen grains are present in the air of Polish cities usually in July, August and at the beginning of September.

In the pollen season in 2019, 2 peaks of Artemisia pollen concentrations were observed as a result of the order of flowering of $A$. vulgaris and A. campestris.

The start of mugwort pollen season in 2019 occurred on average in the middle of July and ended at the turn of August and September;

The duration of the mugwort pollen season varies greatly. Artemisia pollen season in most cities was above 40-80 days long (only in Wroclaw 35 days) and was characterized by different total annual pollen SPI (from 509 in Sosnowiec to 1193 in Lublin).

The highest Artemisia pollen allergen hazard occurred in 2019 in Warsaw, Wroclaw, Opole and Lublin. The number of days with potential acute symptoms of allergy in most patients was low (the highest in Wroclaw -5 days).

The highest variability in the analysed seasons was found in start date, while the lowest in the peak value and SPI value.

\section{References}

1. D'Amato G, Spieksma FT. Allergenic pollen in Europe. Grana 2004, 30: 60-70.

2. Ralska-Jasiewiczowa M, Latałowa M, Wasylikowa $K$ et al (eds). Late Glacial and Holocene history of vegetation in Poland based on isopollen maps. Polish Academy of Sciences, Cracow 2004.

3. Ziello Ch, Sparks TH, Estrella $N$ et al. Changes to Airborne Pollen Counts across Europe. Plos One 2012, 7(4): e34076. DOI: 10.1371/journal.pone.0034076.

4. Spieksma FTM, Corden JM, Detandt $M$ et al. Quantitative trends in annual totals of five common airborne pollen types (Betula, Quercus, Poaceae, Urtica, and Artemisia), at five pollen-monitoring stations in Western Europe. Aerobiologia 2003, 19: 171-184.

5. Mandrioli P, Comtois P, Dominguez E et al. Sampling: Principles and Techniques. In: Mandrioli P, Comtois, Levizzani V (eds). Methods in Aerobiology. Pitagora Editrice Bologna, Bologna 1998: 47-112.

6. Emberlin J, Savage M, Woodman R. Annual variations in the concentrations of Betula pollen in the London area 1961-1990. Grana 1993, 32: 359-363. DOI: 10.1080/00173139309428965.

7. Rapiejko P, Stankiewicz W, Szczygielski K et al. Progowe stężenia pytku roślin niezbędne do wywołania objawów alergicznych. Otolaryngol Pol 2007, 61(4): 591-594.

8. Bogawski P. Fenologia kwitnienia i produkcja pyłku w zróżnicowanych warunkach mikroklimatycznych dużego miasta oraz ich wpływ na przebieg sezonu pytkowego brzozy i bylicy w Poznaniu. Praca doktorska. Uniwersytet im. A. Mickiewicza w Poznaniu, Poznań 2016: 273.

9. Puc M, Rapiejko P, Lipiec A et al. The analysis of mugwort pollen count in selected Polish cities in 2014. Alergoprofil 2015, 11(1): 27-31.

10. Rapiejko P, Lipiec A, Puc M et al. Mugwort pollen season in central and northern Poland in 2015. Alergoprofil 2016, 12(1): 31-35.

11. Weryszko-Chmielewska E, Piotrowska-Weryszko K, Woźniak $A$ et al. Analysis of mugwort (Artemisia) pollen seasons in selected cities in Poland in 2018. Alergoprofil 2018, 14(4): 117-122.

12. Oteros J, Bartusel E, Alessandrini F et al. Artemisia pollen is the main vector for airborne endotoxin. J Allergy Clin Immunol 2019. DOI: 10.1016/j.jaci.2018.05.040.

ORCID

M. Puc - ID - orcid.org/0000-0001-6734-9352

P. Rapiejko - ID - orcid.org/ 0000-0003-3868-0294

A. Lipiec - ID - orcid.org/0000-0003-3037-2326

M. Malkiewicz - ID - orcid.org/0000-0001-6768-7968

K. Dąbrowska-Zapart - ID - orcid.org/ 0000-0002-8976-7739

G. Siergiejko - ID - orcid.org/ 0000-0003-4084-8332

A. Stacewicz - ID - orcid.org/0000-0002-3432-8536

D. Jurkiewicz - ID - orcid.org/0000-0003-3729-2679

E. Kalinowska - ID - orcid.org/ 0000-0003-4821-6882 


\section{ORIGINAL PAPER}

Authors' contributions:

Work input: A - work concept, B - aerobiological data, C - literature review, D - writing the thesis, $\mathrm{E}$ - work correction

Puc M.: A, B, C, D, E; Rapiejko P.: A; Lipiec A.: B, C; Malkiewicz M.: B; Dąrowska-Zapart K.: B; Siergiejko G.: B, C; Dmitruk M.: B; Stacewicz A.: C; Jurkiewicz D.: C; Kalinowska E.: B.

Conflict of interests: The authors declare that they have no competing interests.

Ethics: The contents presented in this paper are compatible with the rules the Declaration of Helsinki, EU directives and standardized requirements for medical journals.

Financial support: Research in Bialystok, Bydgoszzz, Piotrkow Trybunalski, Opole, Olsztyn and Warsaw, funded by Allergen Research Center Ltd.

\section{Corresponding author:}

Malgorzata Puc, Assoc. Prof.

Faculty of Physical, Mathematical and Natural Sciences, University of Szczecin

71-412 Szczecin, Felczaka 3c

e-mail: malgorzata.puc@usz.edu.pl

(c) Medical Education. For private and non-commercial use only. Downloaded from https://www.journalsmededu.pl/index.php/alergoprofil: 26.04.2023; 15:13,39 